\title{
Determinants of Work-Readiness
}

\author{
Siti Nurlaela ${ }^{1}$ Kurjono $^{2}$ Rasto $^{3}$ \\ 1,2,3 Universitas Pendidikan Indonesia \\ Email: siti.nurlaela@upi.edu
}

\begin{abstract}
The purpose of this study is to identify the effects of industrial work practices (Prakerin), family environment, and selfefficacy on student Work-Readiness directly and indirectly. The number of samples involved in this study was 175 students taken by Slovin formula. The ex-post-facto research was employed as the research design in this study. The data were analysed using the Proportional Random Sampling technique. The results of this study showed that industrial work practices, family environment, and self-efficacy both directly and indirectly have a positive and significant effect on Work-Readiness.
\end{abstract}

Keywords: Work-Readiness, Industrial Work Practices (Prakerin), Family Environments, Self-Efficacy

\section{INTRODUCTION}

According to the Regulation on the National Education System article 3 no. 20 of 2003 [1], Vocational High Schools (SMK) are regarded as the function of national education to develop the ability, character building, and respected national civilization in order to educate the life of the nation [2]. In addition, this type of school also aims to develop the potentials of students as believing and pious human beings in the God Almighty, noble, healthy, knowledgeable, capable, creative, independent, democratic and responsible citizens [3, 4].

"Through the government's policy on providing Vocational High Schools, it is expected that this type of school can provide education on entrepreneurship knowledge, soft skills, and field work practices as the set objectives. In addition, it is also expected that the vocational students can be knowledgeable, skilful, and competitive individuals in the working world.

Vocational education is viewed as education aimed at preparing the ability of the students to work in certain fields. Therefore, it can be concluded that the vocational school is an educational program aimed at preparing the student work readiness so that they can get into the employment immediately after completing education at the high school level [5].

Recently, it is considered as a classic issue of vocational education in Indonesia generally that the link and match between the output of vocational education and the business / industrial world has not been achieved yet. As a matter of fact, the existence of Vocational
Schools in preparing the expected work forces still has not optimal.

Initially, the vocational school graduates are expected to fill employment opportunities in the business world / industrial world for they have certification through competency testing. In fact, many vocational school graduates unfortunately become unemployment. This worrying fact are indicated by the data released by the Central Statistics Agency (CSA) which stated that the number of unemployed people in Indonesia in August 2015 reached 7.6 million people. The Open Unemployment Rate (OUR) underwent increase from $5.8 \%$ in February 2015 to 6, 18\% in August 2015. In August 2015 alone, the OUR for vocational education was at the highest position of $12.65 \%$ and increased by $3.60 \%$ from the OUR data in February 2015 [6].

The low number of vocational school graduates who do not get a job is influenced by several factors. Basically, Work-Readiness is one of the factors that can influence individuals who will enter the working world.

The job training is part of a curriculum that connects the gap between theory and practice as well as between classroom education and real life in the industry. In fact, it is expected to result in a valuable learning experience and enhance the importance of educational, and personal and social performance programs $[7,8]$. 


\section{LITERATURE REVIEW}

\subsection{Work-Readiness}

Work-Readiness is highly important for vocational school students. In fact, in a very short time, some or all students will face a higher level of life in the workplaces. In general, the work preparation that should be paid attention is developing the work ability required by certain types of job.

According to the dictionary of psychology, WorkReadiness contains two definition covering: (a) the state of being prepared to react or respond, (b) the level of development of maturity which is beneficial to practice something [6,9]. Readiness is the overall condition of a person that makes him or her ready to give a response or answer in a certain way on a certain situation [9].

The Law of readiness can be understood in the context that if the reaction to the stimulus is supported by the readiness to act, then the reaction becomes satisfactory [10]. This statement implies that if students do an activity supported by knowledge, skills, attitudes, and mentality as a means of carrying out activities properly, the results will be more satisfying. The principles for the development of readiness are as follows:

All aspects of growth interact and form readiness collectively, namely ability of readiness.

A person's experience influences the physiological growth of an individual.

Experiences have a cumulative effect in the development of individual personality functions, both physically and spiritually.

If the readiness of a person in carrying out certain activities is shaped, then it occurs in a certain moment in one's life.

Building Work-Readiness for vocational students is important in producing competitive and successful graduates in the working world. Vocational education has a close relationship with the working world or industry. Hence, practical learning and trainings play a crucial key to improve the quality of graduates in order to adapt in the working world [11].

The importance of work experience in shaping the Work-Readiness of students is reflected in the participation of the students in the internship program [12]. The Work-Readiness of students as one of the job requirements in this case is depended on several factors, such as industrial trainings. In addition, it is important to develop students in balance based on job requirements in order to prevent obstacles [13, 14]. The experience gained during industrial work practices will make students more mature in their work preparation. In fact, the experience of field work provides important preparation in the working world.

With respect to the Work-Readiness, it is regarded as a set of required skills and behaviours to work in various fields. Particularly, Work-Readiness skills are sometimes called as soft skills, job skills, or Work-Readiness skills. Moreover, it is required to get the maximum work results in accordance with the set targets [15]. Furthermore, Work-Readiness also is depended on the level of mental maturity and emotional conditions which include the willingness to cooperate with others, be critical, accept responsibility, have ambition to move forward, and be able to adjust to the Business World / Industrial World.

Work-Readiness of students is influenced by two factors, internal and external factors. Internal factors consist of maturity, creativity, interest, intelligence talent, independence of science mastery, and motivation of students. On the other hand, external factors comprise family roles, equipment's, school facilities, community roles, information on the working world, and work experience [8]. The graduates who have Work-Readiness are those who have logical and objective considerations, the ability to cooperate, critical thinking, responsibility, adaptability, and readiness to progress [16].

The Work-Readiness of vocational students is also based on the mastery of educational materials and vocational trainings in each student. With high mastery of knowledge, individuals will be better ready to carry out their activities or in other words students who have high learning achievement are those who have high Work-Readiness.

\subsection{Family Environment}

With respect to the Work-Readiness of vocational students, family environment is considered as one of the important external factors. In addition, it also has a huge contribution in preparing students to become entrepreneurs in the future [2].

Parents are considered as the main agents in shaping the attitude of their children and in the same time protecting them [17]. In this regard, family is initially responsible for the education of the children so that the family is viewed as the foundation for educating behaviour and personal development of the children. It is undeniable that family environment can be a conducive environment for training and sharpening entrepreneurial characters. These characters are also expected to be a provision for children to find out their interest in the future. In the family environment, a child gets inspiration and entrepreneurial supports from the family. In an indirect way, there is an activity in the family that can be a means of learning entrepreneurship.

As mentioned in advance, family environment has a huge contribution in preparing children to become 
entrepreneurs in the future [18]. In fact, it is the first and foremost environment that teaches good life attitudes and values.

Many people believe that the working world is very closely related to the environment, relationships, tasks of work that require good physical or psychological mental readiness, the ability to communicate, and any other required things that need seriousness and special abilities. In particular, ability and mental readiness are considered as one of the special abilities that must be possessed by a prospective job seeker. The ones with good mental maturity will be able to improve their self-efficacy or confidence in facing a new environment in the workplaces [6].

\subsection{Self-Efficacy}

Self-efficacy is an individual's subjective belief functioned to overcome a problem or task and take the required actions to achieve the desired goals [19]. Bandura stated "self-efficacy is a strong personal belief in skills and abilities to initiate the tasks and lead them to success" [7, 20]. As a matter of fact, one of the internal factors in oneself is self-efficacy [3]. In addition, Bandura also stated that self-efficacy is basically considered as the result of the cognitive processes of decisions, beliefs, and expectations regarding how deep individuals estimate their ability to perform certain tasks or actions in order to achieve the expected results [3, 4].

Self-efficacy is also viewed as self-assessment with respect to good or bad, right or wrong, and able or unable and it was done as required $[3,21]$. In principle, selfefficacy is the result of cognitive processes in the form of decisions, beliefs or expectations regarding how deep individuals estimate their ability to perform certain tasks or actions in order to achieve the expected results [3,22]. Therefore, students can maximize their learning achievements, form an optimistic attitude, and remain persistent in facing every existing challenge in order to compete in schools and workplaces [3].

The vocational school students who are ready to compete in the working world are in demand of high selfefficacy. Therefore, students can maximize their learning achievements, form an optimistic attitude, and remain persistent in facing every existing challenge in order to compete in schools and workplaces $[1,3]$.

To prepare the students in the working world, they are required to do industrial work practices. This industrial work practice is an exercise program carried out in the field or outside the classroom. Additionally, it is also a series of learning activities as an integral part of the training program. Industrial work practices are an important component in the training system to develop participants' knowledge and management skills [23].

\section{METHODS}

This present study was a quantitative study. The ex post facto research was also employed as the research design. In this study, the data were taken from the past events [14]. Since this study employed a quantitative approach, it is in fact a process of finding knowledge through the data in the form of numbers. Additionally, it was also used as a tool to discover the to-be-known information. Furthermore, it aimed at explaining or describing phenomena based on the focus of the problems under investigation and based on facts in field.

As a matter of fact, "many quantitative studies were in demand primarily in the use of numbers, starting from the data collection, the data interpretation, and the display of the results". In addition, understanding the research conclusions would be better if also tables, graphs, charts, images or other displays are inserted as data" [24]. In addition, this type of study was also used in the Field Research in which it facilitated the direct observations in order to obtain the needed information. Furthermore, this type of study was also used in the library research in which the study was carried out using literature from previous studies.

In this study, the data was collected by the means of questionnaires. It was in fact carried out by disseminating or distributing questionnaires to chosen respondents [6]. The closed questionnaires were used in this present study [6]. Therefore, the respondents were supposed to answers the questions using the choices set up by the researcher. In this phase of study, the questionnaires were used to examine the research variables of Field Work Practices (PKL), family environment, self-efficacy, and WorkReadiness using a Likert scale. Basically, the Likert scale was used to measure the attitudes, opinions, and perceptions of a person or group of people about social phenomena [15]. Additionally, through this Likert scale, the variables were transformed into indicators of the variables [15]. Afterwards, the indicators were used as a reference for compiling the items.

Questionnaire technique was regarded as a technique of data collection conducted by giving a set of to-beanswered questions or written statements to the respondents [13]. Moreover, it was also considered as an efficient data collection technique when the researcher was highly familiar with the to-be-measured variables and the expectations of the respondents. With respect to the present study, the questionnaires used to measure the Industrial Work Practices (Prakerin), family environment, self-efficacy, and Work-Readiness can be answered through the following answer alternatives covering (5) Strongly Agree; (4) Agree; (3) Doubt (2) Disagree; (1) Strongly Disagree [13].

The quantitative approach was employed in this study for the forms of the data were portrayed in numbers, analysed using statistics and described in terms of the the 
results descriptively. In this study, there were three variables, two independent variables and one dependent variable (Industrial Work Practices (Prakerin) (X1), family environment (X2), Self-Efficacy (Y), and WorkReadiness $(\mathrm{Z})$ ). Then, the data were processed using the variable intervening path analysis regression testing techniques [24].

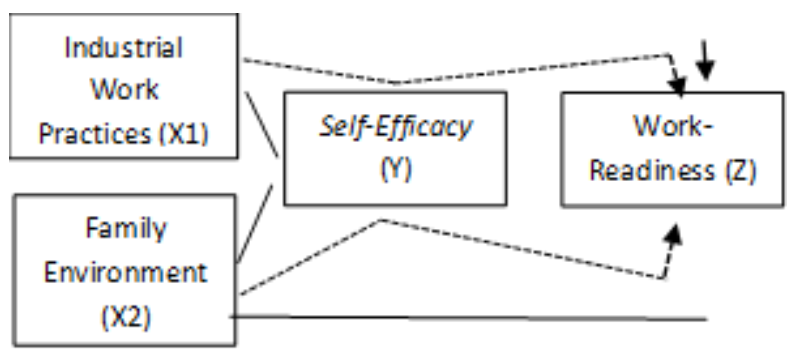

Figure 1. Framework

Information:

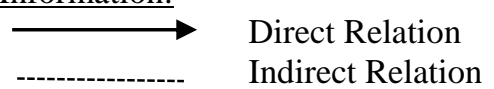

Table 1. Descriptive Analysis Of Research Variables

\begin{tabular}{|c|c|c|c|}
\hline Industrial Work Practices (X1) & $\%$ & & Average \\
\hline $\begin{array}{l}\text { 1. Student Discipline Aspects } \\
\text { 2. Cooperation } \\
\text { 3. Initiative and Creativity } \\
\text { 4. Diligence / Ability in Working } \\
\text { 5. Responsibility } \\
\text { 6. Attitudes/ Behaviors in Working }\end{array}$ & $\begin{array}{l}84 \\
88 \\
84 \\
88 \\
84 \\
87\end{array}$ & Very High & 85 \% (Very High) \\
\hline Family Environment (X2) & $\%$ & & Average \\
\hline $\begin{array}{l}\text { 1. Parent Education Methods } \\
\text { 2. Relation among family } \\
\text { 3. Atmospheres of the House } \\
\text { 4. Family Economy Condition } \\
\text { 5. Cultural Backgrounds } \\
\text { 6. Parent Definition }\end{array}$ & $\begin{array}{l}94 \\
91 \\
92 \\
92 \\
95 \\
81\end{array}$ & Very High & $\begin{array}{c}95 \% \\
\text { (Very High) }\end{array}$ \\
\hline Self-Efficacy $(Y)$ & $\%$ & & Average \\
\hline $\begin{array}{l}\text { 1. Magnitude: } \\
\text { Difficulty Levels control emotions during encountering } \\
\text { problems } \\
\text { 2. Strength: } \\
\text { Students' beliefs in carrying out certain things in work } \\
\text { success } \\
\text { 3. Generally: } \\
\text { Students' beliefs in self-ability in a particular job }\end{array}$ & $\begin{array}{l}88 \\
91 \\
90\end{array}$ & Very High & 89\% (Very High) \\
\hline Work-Readiness $(Y)$ & $\%$ & & Average \\
\hline $\begin{array}{l}\text { 1. Maturity } \\
\text { 2. Ability and Skills }\end{array}$ & $\begin{array}{l}83 \\
84\end{array}$ & Very High & 83 \% (High) \\
\hline
\end{tabular}

Based the Framework above, the study hypothesis based on its literature and model can be formulated as follows:

$\mathrm{H} 1=$ There is an effect of Industrial Work Practices on Work-Readiness [14].

$\mathrm{H} 2=$ There is an effect of Family Environment on WorkReadiness.

$\mathrm{H} 3=$ There is an effect of Industrial Work Practices on Self-efficacy.

H4 = There is an effect of Family Environment on SelfEfficacy.

H5 = There is an effect of Self-Efficacy on the WorkReadiness.

$\mathrm{H} 6=$ There is an indirect effect of Industrial Work Practices in Work-Readiness through Self-Efficacy.

$\mathrm{H} 7 \quad=\quad$ There is an indirect effect of Family

Environment on Work-Readiness through Self-Efficacy.

\section{RESULTS AND DISCUSSION}

The following tables are the results of the descriptive analysis of each variable under investigation: 


\begin{tabular}{|l|l|l|l|}
\hline 3. Attitudes and Mental & 85 & & \\
\hline
\end{tabular}

Sources: Processed data

The empirical description of Industrial Work Practices (Prakerin) can be viewed from the following indicators: (1) Work Discipline Aspects, 1 statement, (2) Collaboration, 1 statement, (3) Initiative / Creativity, 1 statement, (4) Diligence / Ability in Work, 1 statement, (5) Responsibility, 1 statement, (6) Attitude / Behavior in work, 1 statement. Based on the calculation, the indicators of Industrial Work Practices are in the very high condition because it reaches $84 \%, 88 \%, 84 \%, 88 \%$, $84 \%$ and $87 \%$ with an average dimension of $85 \%$. In the empirical description of the family environment, there are six statements: (1) parent education methods, (2) relation between family members, (3) atmosphere of the house, (4) family economy condition, (5) cultural background, and (6) definition of parents. Based on the calculations, it is shown that the various indicators of the Family Environment resulted in 94\%, 91\%, 92\%, 92\%, $95 \%$, and $81 \%$, with an average of $95 \%$. Then, the empirical description of Self-Efficacy is taken from the dimensions of (1) Magnitude (the difficulty level of emotion control in facing problems) $88 \%$, (2) Strength (students' beliefs in doing something towards work success) 91\%, (3) Generality (Students' beliefs against self-ability) $90 \%$, with an average of $89 \%$ (very high). In the empirical description of Work-Readiness, there are 5 statements from 3 indicators covering (1) maturity, 83\%, (2) ability and skills, $84 \%$ (3) attitudes and mentality, $85 \%$ with the average dimension of $83 \%$.

The results of the regression analysis of the intervening variables are shown in Table 2 [17].

Table 2. Coefficient Model Of Path 1

\begin{tabular}{|l|r|r|r|c|}
\hline \multicolumn{5}{|c|}{ Summary Model } \\
\hline Model & $\mathrm{R}$ & $\begin{array}{c}\mathrm{R} \\
\text { Square }\end{array}$ & $\begin{array}{c}\text { Adjusted } \\
\mathrm{R} \text { Square }\end{array}$ & $\begin{array}{c}\text { Std. Error of } \\
\text { the } \\
\text { Estimate }\end{array}$ \\
\hline 1 & $.221^{\mathrm{a}}$ & 0,490 & 0,038 & 3,55632 \\
\hline \multicolumn{5}{|l|}{$\begin{array}{l}\text { a. Predictors: (Constant), FAMILY ENVIRONMENT (X2), } \\
\text { INDUSTRIAL WORK PRACTICES (X1) }\end{array}$} \\
\hline
\end{tabular}

Table 3. Regression Coefficient Model 1

\begin{tabular}{|c|c|c|c|c|c|c|}
\hline & \multirow{2}{*}{ Model } & \multicolumn{2}{|c|}{ Unstandardized Coefficients } & Standardized Coefficients & \multirow[t]{2}{*}{$\mathrm{t}$} & \multirow[t]{2}{*}{ Sig. } \\
\hline & & B & Std. Error & Beta & & \\
\hline \multirow[t]{3}{*}{1} & (Constant) & $-2,245$ & 12,432 & & $-0,181$ & 0,857 \\
\hline & $\begin{array}{l}\text { INDUSTRIAL } \\
\text { WORK } \\
\text { PRACTICES (X1) }\end{array}$ & 0,562 & 0,268 & 0,156 & 2,095 & 0,038 \\
\hline & $\begin{array}{l}\text { FAMILY } \\
\text { ENVIRONMENT } \\
(X 2)\end{array}$ & 0,861 & 0,430 & 0,149 & 2,002 & 0,047 \\
\hline
\end{tabular}

In the outputs of the Regression Coefficient Model 1 in Table 3, it is obvious that the significance value of the two variables are $\mathrm{X} 1=0.038$ and $\mathrm{X} 2=0.047<0.05$. Therefore, it shows that the Regression Model 1, the X1 and X2 variables have a significant effect on Y $[11,17$, 20]. The number of $R 2$ or $R$ Square values as portrayed in Table 2 Summary Model is 0.490 . hence, it shows that the X1 and X2 have an effect on Y around $49 \%$. Then, the remaining $51 \%$ is the effect of the other variables excluded in the study.

Meanwhile, e1 value can be discovered using the formula of $\mathrm{e} 1=\sqrt{ }(1-0.49)=0.51$.
Table 4. Coefficient Model of Path 22

\begin{tabular}{|c|c|c|c|c|}
\hline \multicolumn{5}{|c|}{ Summary Model } \\
Model & $R$ & $\begin{array}{c}\text { R } \\
\text { Square }\end{array}$ & $\begin{array}{c}\text { Adjusted } \\
R \\
\text { Square }\end{array}$ & $\begin{array}{c}\text { Std. Error of the } \\
\text { Estimate }\end{array}$ \\
\hline 1 & $.464 a$ & 0,216 & 0,202 & 1,63022 \\
\hline \multicolumn{6}{|c|}{$\begin{array}{c}\text { a. Predictors: (Constant), SELF-EFFICACY (Y), FAMILY } \\
\text { ENVIRONMENT (X2), INDUSTRIAL WORK PRACTICES } \\
(\mathrm{X} 1)\end{array}$} \\
\hline
\end{tabular}


Table 5. Regression Coefficient Model 2

\begin{tabular}{|c|c|c|c|c|c|c|}
\hline & \multirow[t]{2}{*}{ Model } & \multicolumn{2}{|c|}{$\begin{array}{c}\text { Unstandardized } \\
\text { Coefficients }\end{array}$} & \multirow{2}{*}{$\begin{array}{c}\begin{array}{c}\text { Standardized } \\
\text { Coefficients }\end{array} \\
\text { Beta }\end{array}$} & \multirow[t]{2}{*}{$\mathrm{t}$} & \multirow[t]{2}{*}{ Sig. } \\
\hline & & B & Std. Error & & & \\
\hline \multirow[t]{4}{*}{1} & (Constant) & 7,518 & 5,699 & & 1,319 & 0,189 \\
\hline & $\begin{array}{l}\text { INDUSTRIAL WORK } \\
\text { PRACTICES (X1) }\end{array}$ & 0,325 & 0,124 & 0,179 & 2,610 & 0,010 \\
\hline & FAMILY ENVIRONMENT (X2) & $-0,009$ & 0,199 & $-0,003$ & $-0,045$ & 0,016 \\
\hline & SELF-EFFICACY (Y) & 0,202 & 0,035 & 0,401 & 5,768 & 0,000 \\
\hline
\end{tabular}

Based on the results of the Regression Coefficient Model 2 in Table 4, it is obvious that the significance values of the three variables are $\mathrm{X} 1=0.010, \mathrm{X} 2=0.016$, and $Y=0.000$ and they are smaller than 0.05 . Therefore, it can be concluded that regression model 2, the X1, X2, and $\mathrm{Y}$ variables, has a significant effect on $\mathrm{Z}$. The magnitude of R2 or R Square in the aforesaid summary model in the Table above is 0.216 . This data show that $\mathrm{X} 1, \mathrm{X} 2$, and $\mathrm{Y}$ to $\mathrm{Z}$ are $21.6 \%$ while the remaining percentage $78.4 \%$ is the contribution from other variables excluded in this study and this the value of e $2=\sqrt{ }$ (1$0,216)=$ is $0.7840(\mathrm{e} 2=\sqrt{ }(1-0,216)=0.7840).[11,19]$.

\section{CONCLUSION}

In a bottom line, based on the results of the study and hypothesis testing [22], it can be concluded that: (1) Industrial Work Practices have a positive and significant effect on Work-Readiness [9], (2) Family Environments have a positive and significant effect on Work-Readiness, (3) Industrial Work Practices has a positive and significant effect on Self- Efficacy, (4) Family Environments have a positive and significant effect on Self Efficacy, (5) Self-Efficacy has a positive and significant effect on Work-Readiness, (6) Industrial Work Practices (Prakerin) indirectly through Self-Efficacy have a positive and significant effect on Work-Readiness [15], and (7) Family Environments indirectly through SelfEfficacy have a positive and significant effect on WorkReadiness [15].

\section{REFERENCES}

[1] J. W. Santrock, Educational Psychology Second Edition, Jakarta: Kencana, 2007, pp.546.

[2] Saroni. (2012). Lingkungan belajar. Diakses pada 29/11/2013 dari http://hendri ansdiamond.blogspot.com/2012/01/ lingkunganbelajar-html [6][12].

[3] Undang-Undang Sistem Pendidikan Nasional Nomor 20 Tahun 2003 pasal 3 definisi SMK (Sekolah Menengah Kejuruan)

[4] M. N. Ghufron, R S. Rini, Psychological Theories, Jogjakarta: Ar-Ruzz Media. 2010.

[5] Djohar, Pendidikan Teknologi dan Kejuruan. Dalam Ilmu dan Aplikasi Pendidikan. Bandung: Pedagogiana Press, 2007.

[6] Badan Pusat Statistik (BPS), Keadaan Ketenagakerjaan Agustus 2015, Berita Resmi Statistik No 103/11/Th. XVIII, 5 November 2015.

[7] J. M. Laguador, "Engineering Students' Academic and on-the-Job Training Performance Appraisal Analysis," International Journal of eEducation, eBusiness, e-Management and eLearning Vol.3 No.4

[8] Mandiriyanto, "Pengaruh Praktik pada Siswa Kelas XII SMK N 2 Tegal, Skripsi, Semarang: FE Unnes, 2013

[9] A. F. Yanto, Ketidak Siapan Memasuki Dunia Kerja Karena Pendidikan, Jakarta: Dinamika Cipta, 2006

[10] J. P. Chaplin, Kamus lengkap psikologi, Jakarta: PT Raja Grafindo Persada, 2011

[11] Dalyono, Psikologi Pendidikan, Jakarta: Rineka Cipta, 2015

[12] Wena, Strategi pembelajaran Inovatif Kontemporer. Jakarta: Bumi Aksara, 2009.

[13] L. H. Teck Perceived Job Readiness of Business Students at the Institutes of Higher Learning in Malaysia, International Journal of Advances in Management and Economics, Malasyia: Issue 6 Vol.1, 2012, pp. 151.

[14] Aminuddin, M. Najib, Relationship of job involvements on vocational school students' job satisfactions in industrial training, International Journal of Vocational and Technical Education. 
Malasyia: Academic Journals Vol.5(1), 2013, pp. 17.

[15] S. Arikunto, Metodologi Penelitian. Jakarta: PT. Rineka Cipta. 2002.

[16] Firdaus, Z. Zamzam, Pengaruh Unit Produksi, Prakerin Dan Dukungan Keluarga Terhadap Kesiapan Kerja Siswa SMK, Jurnal Pendidikan Vokasi, vol 2(3), 2012.

[17] A. Fitriyanto, Ketidakpastian Memasuki Dunia Kerja Karena Pendidikan, Jakarta: Dineka cipta. 2006.[19].

[18] M. C. Clarke, et al, The acquisition of family financial roles and responsibilities, Family and Consumer Sciences Research Journal. Vol 33(4), 2005, pp. 321-340.

[19] Saroni, (2012), Lingkungan belajar, Diakses pada 29/11/2013 dari http://hendri ansdia mond.blogspot.com/2012/01/lingkungan-belajarhtml [8][4].
[20] A. Lukmayanti, Hubungan Efikasi Diri dengan Minat Berwirausaha Siswa Kelas XII Paket Keahlian Jasa Boga di SMK Negeri 6 Yogyakarta, Undergraduate thesis, Universitas Negeri Yogyakarta, 2012 [4][6].

[21] A. Bandura, Self-efficacy. In V. S. Ramachaudran (Ed.), Encyclopedia of human behavior, New York: Academic Press, vol. 4, 1994, pp.71-81.

[22] Alwisol, Personality Psychology, Malang: UMM Press, (Indonesian Origin), 2009.

[23] M. N, Ghufron, R. Rini, Teori-teori Psikologi, Jogjakarta: Ar-Ruzz Media. 2011

[24] S. Arikunto, Metodologi Penelitian, Jakarta: PT. Rineka Cipta, 2002.

[25] A. Suharsimi Prosedur Penelitian Suatu Pendekatan Praktik. Jakarta: Asdi Mahasatya, 2010 